\title{
VR Application for Technology Education in a Public Library
}

$\begin{array}{ll}\begin{array}{l}\text { Harri Holappa } \\ \text { Oulu City Library } \\ \text { Oulu, Finland } \\ \text { harri.holappa@ouka.fi }\end{array} & \begin{array}{l}\text { Ilya Minyaev } \\ \text { University of Oulu } \\ \text { Oulu, Finland } \\ \text { ilya.minyaev@oulu.fi }\end{array} \\ \begin{array}{l}\text { Johanna Ylipulli } \\ \text { University of Helsinki } \\ \text { University of Oulu } \\ \text { Helsinki, Finland } \\ \text { johanne.ylipulli@elsinki.fi }\end{array} & \begin{array}{l}\text { Matti Pouke } \\ \text { University of Oulu } \\ \text { VTT Technical Research Centre } \\ \text { of Finland } \\ \text { Oulu, Finland } \\ \text { matti.pouke@oulu.fi }\end{array} \\ \begin{array}{l}\text { Sami Rautiainen } \\ \text { Oulu City Library } \\ \text { Oulu, Finland } \\ \text { sami-ville.rautiainen@ouka.fi }\end{array} & \begin{array}{l}\text { Timo Ojala } \\ \text { University of Oulu } \\ \text { Oimo.ojala@oulu.fi }\end{array} \\ & \end{array}$

Permission to make digital or hard copies of part or all of this work for personal or classroom use is granted without fee provided that copies are not made or distributed for profit or commercial advantage and that copies bear this notice and the full citation on the first page. Copyrights for third-party components of this work must be honored. For all other uses, contact the Owner/Author.

MUM'18, November 25-28, 2018, Cairo, Egypt
Copyright $@ 2018$ is held by the owner/author(s).

ACM ISBN 978-1-4503-6594-9/18/11.

https://doi.org/10.1145/3282894.3289719

\begin{abstract}
In this video paper we report on our experiences of deploying a VR point at a public library for the purpose of educating library patrons on VR technology. The primary application offered at the VR point is called Virtual Library, a VR application developed specifically for the Oulu City Library. The Virtual Library application provides an immersive virtual interface into selected library services, as well as allows library patrons to browse literature recommendations inside genre-specific fantasy realms. Based on the observations of the first week weeks of deployment, the VR point and the Virtual Library are successful approaches for technology education in a public library.
\end{abstract}

\section{Author Keywords}

Digital library services; technology education; mirror world; hybrid space; fantasy worlds; participatory design.

\section{ACM Classification Keywords}

H.3.7 [Digital Libraries]: Dissemination.

\section{CCS Concepts}

-Human-centered computing $\rightarrow$ Virtual reality; Participatory design; - Information systems $\rightarrow$ Digital libraries and archives; 


\section{Introduction}

In this paper we report on deploying an experimental Virtual Reality (VR) prototype application called Virtual Library ([4]) for technology education in a public library. We explain the background and objectives, and focus especially on how the Virtual Library supports the library's role in the society, as well as library's main goals, values and visions. Furthermore, we briefly describe the workshop-based development process that was utilized to create the prototype and how the Oulu City Library has experienced offering the Virtual Library as a service at its premises.

The Virtual Library concept is based on a long-term collaboration between the University of Oulu and the Oulu City Library. In spring 2016 we jointly decided to experiment with VR and AR technologies with the City Library. The aim was broadly to produce novel library services and experiences related to Library's materials [9]

\section{Libraries as sites of learning and experiencing}

The collaboration process with the Oulu City Library was launched by realizing a preliminary interview with the library administration. This interview provided us with background information about the current status of libraries in Oulu and in Finland, and proved us that utilizing VR in library context would be fruitful. The interview lasted a little bit over two hours and was based on a thematic semi-structured interview method.

On national scale, libraries in Finland have a good public image and they are highly popular [7]. While other European countries are closing down their libraries, Helsinki is currently building a massive new one, the Helsinki Central Library, in the center of the capital. The pricetag of the architecturally ambitious building is 98 million euros [8]. The interview we conducted with the library administration re- flected this tendency: although the amount of borrowed books is slightly diminishing, the number of library patrons is the same if not even increasing. Citizens seem to hunger for non-commercial, calm public space, where they can study, work and spend time [1]

Contemporary libraries were described as versatile, lowthreshold cultural centers; a public library can be seen as an integral element of a democratic society. The interviewees told that libraries have two broad main tasks: to provide information and experiences equally to everyone. This includes educating citizens about new technologies and their possibilities; this is even mentioned in the Finnish library legislation. Public libraries have provided IT education for long time, and our Oulu interviewees told it started already in the 1990s. They also emphazised that nowadays the idea is not just to educate people about elementary technologies but to offer citizens a possibility to familiarize themselves with new phenomena which are not yet necessarily part of everyday life. In a democratic society, everybody should have a chance to try out also technologies they cannot afford or they do not want to acquire for other reasons.

This educational aspect was one of the main reasons fo developing the Virtual Library prototype. Secondly, the idea was to explore what kinds of possibilities VR technologies offer in expanding and enhancing the library services and renewing them in a subtle way. Third, the idea was to present library content, especially literature, in a new, exiting way which could potentially attract patrons that libraries sometimes find hard to reach, such as teenagers.

\section{Development process}

Overall, the Virtual Library application is intended to act as a flexible and easy-to-extend platform for representing 
library's offerings in a new form. In addition to prototype services described in the following pages, it could be used e.g. as a new social arena for library's patrons, or to provide immersive journalism to library patrons [2].

Participatory Design was chosen as the primary method for developing the Virtual Library prototype [6]. We set up two workshop sessions to create ideas and gather specifications for the prototype. Furthermore, the design and development process has included numerous meetings with the researchers and library staff. The design process reflects the democratic values of the library, as different stakeholders were invited to co-create ideas for the new service.

\section{Workshop 1}

The development for the Virtual Library prototype started by setting up a first multi-stakeholder workshop, arranged in cooperation with the Oulu City Library [9]. The aim was to bring researchers, library staff and library patrons (35 participants) together to create ideas and preliminary concepts for a Hybrid Library, a vision of a future library, where VR and augmented reality (AR) technologies as well as 3D web would enhance the library experience and extend library patron's experience of the physical library and its services. After analyzing the recorded material collected in the workshop with thematic analysis, we decided to concentrate on VR first and develop services and ideas connected to AR later.

\section{Workshop 2}

A second workshop was arranged half a year later. It was more focused as we concentrated only on VR; the idea was to develop certain chosen ideas, drawn from the workshop 1 , forward together with the participants (17). In this workshop, we utilized an intercative prototype of the Virtual Library to give to participants a better idea of the potential of this particular technology. The prototype piloted one of the central ideas that came up in the initial workshop: The virtual representation of the physical library, a mirror world, was connected with fantasy worlds that exist only in digital reality; this structure intends to reflect how books (and other library content) act as a portal transporting people into alternate realities. Again we recorded all the activities and analyzed them with thematic analysis. All the central features and services of the VIrtual Library are based on the suggestions that came up in the workshops; we chose the ideas that kept coming up repeatedly. The concept for Virtual Library was created after all the material from the two workshops had been analyzed; it was presented to the library staff and polished according to their feedback.

\section{VR Application}

The Virtual Library prototype is an interactive room-scale Virtual Reality (VR) application in which the user is able to freely roam throughout four different levels and interact with various thematic hotspots. The application runs on desktop Windows PC and utilizes Oculus CV1 with Touch controllers as VR hardware. The Virtual Library was developed with Unreal Engine (most recent version using UE 4.17). The 3D models and textures used for the levels are a combination of self modeled assets as well assets purchased from the Unreal Marketplace. The application can utilize multiple servers allowing multiplayer across all levels, however the multiplayer functionality has not yet been tested.

\section{Navigation and Interaction}

Virtual Library is not particularly designed for gamers only, but instead for all users of the library. For this reason we reduced the Cybersickness effect caused by the application by eliminating the vection effect from navigation [5] aiming for more comfortable experience. Instead of continuous virtual movement, the navigation within the environment is based solely on real walking and instantaneous telepor- 


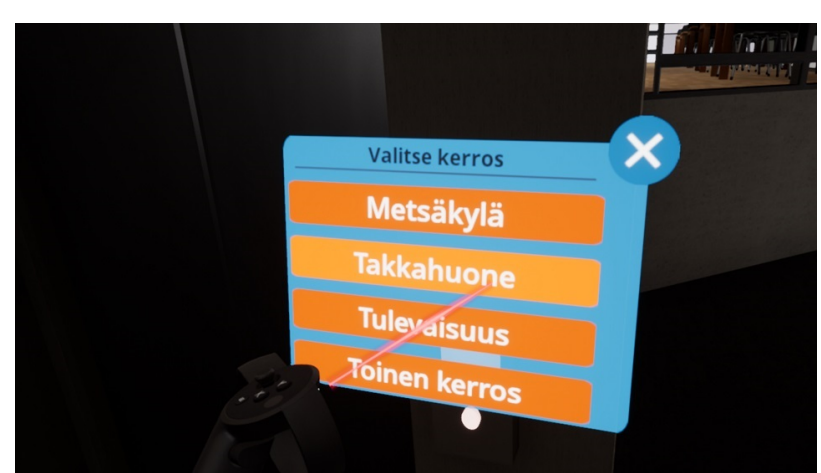

Figure 1: Elevator interface

tation; this has been seen as an effective way to reduce vection-based Cybersickness [3]. The user can freely move within the tracking range of the Oculus tracking system moving larger distances by Unreal Engine default teleportation mechanism.

The user can utilize the Oculus Touch controllers to interact with various points within the environment. Most interaction is point-and-click based, the user indicating an object of interest through pointing and subsequently confirming a selection by squeezing the upper trigger button. There are also objects that the user can pick up with the same trigger button. Some of the interactive objects contain ingame menus that are implemented as Unreal 3D Widgets. One of these menus is the elevator button, which transports the users into the fantasy levels; it is invoked on top of the user's virtual left hand with a separate menu button (see Fig. 1).

\section{Different VEs}

The Virtual Library consists of four separate virtual environments (VEs). These are the City Library, Fantasy Village, Study and Future Alley. The themes of the VEs were chosen according to the workshop findings and each of them contains specific interactive services.

\section{City Library}

The starting VE mirrors the bottom two floors of the actual physical library. It entails a function that enables searching items from the actual library database; the user can also browse their online reviews ${ }^{1}$. There is also a possibility to view navigation instructions to the corresponding virtual locations of the actual book given its location in the physical library. Furthermore, the City Library VE also contains a virtual art exhibition as well as an elevator which can be used to transport users to the fantasy levels Fantasy Village, Study and Future Alley.

Fantasy Village

The Fantasy Village VE resembles a large fairy-tale forest with a medieval village. This VE contains book suggestions authored by the library staff. The recommendations in this level are mostly fantasy literature targeted for young adults. To enhance the experience, the book suggestions are hidden within the virtual objects in the VE; they can be invoked by pointing and clicking the corresponding object. An example can be seen in figure 2 .

Study

The Study VE represents a cozy room with a fireplace. It contains several interactive objects the user can play with, such as books, bottles and an animated cat, as well as an 'magic book' for collaborative writing of stories. The writing takes place utilizing a magnet metaphor; the user has a set 


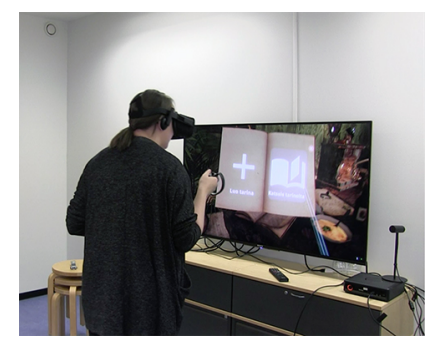

Figure 3: A user operating the collaborative writing service

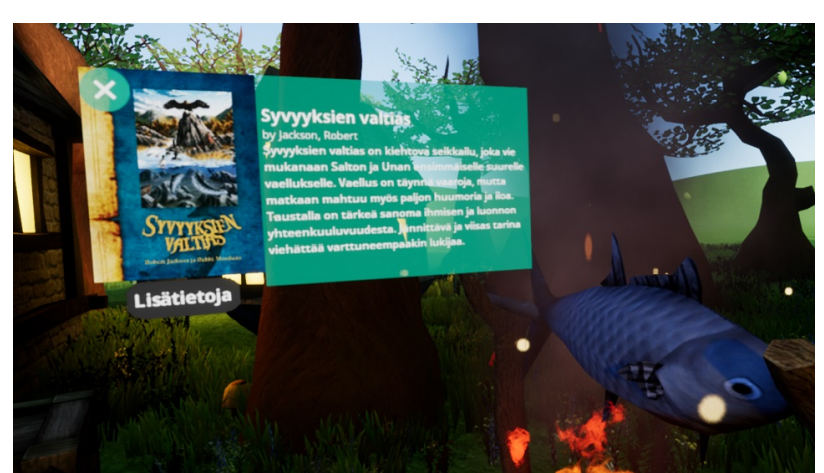

Figure 2: A book recommendation object in the Fantasy Village level

of words from which he/she can drag and drop words to the book page (see Fig. 3 . The user can save the story so that other users can view or continue it later.

\section{Future Alley}

The Future Alley VE is a slightly gloomy urban environment, resembling future visions of science fiction. It offers similar services as the Fantasy Village VE, i.e. book suggestions. Within this VE, the theme of the literature is future and science fiction instead of fantasy.

\section{VR Point in Oulu City Library}

The Virtual Library is on display at the Oulu City Library at the so-called VR point (see Fig. 4) that was opened on September 18th, 2018. There, library patrons have the possibility to try out Virtual Library when they are passing by, or alternatively by reserving a 30-minute slot beforehand. A VR instructor is present at the point at all times, helping users with the VR equipment and application if needed. The public VR point also supports collection of research data as we log anonymous quantitative user data from each VR session with game analytics mechanisms.

Informed by the experiences from these first few weeks, the library staff has made some initial findings about the value of this novel library service.

Firstly, the usage numbers of the VR point have exceeded expectations. The VR point operates on weekdays and only on relatively quiet periods of time - from 10 a.m. to 15 p.m., or from 12 p.m to 18 p.m - but nevertheless, it seems to have attracted continually at least one library patron per hour on average. This is higher than many of the other offerings that have been situated previously at the same location. Furthermore, the feedback from the patrons has, as a rule, been positive. Even some of the senior patrons, while a rare population segment to try out the VR application, have still been intrigued by the novelty of the technology. Already, the Virtual Library seems to have been an effective service to spearhead the library's attempts to provide its patrons opportunities for technology education and new experiences.

Secondly, the VR point has proved to be a sufficiently simple to setup, supervise and maintain, while following good standards for safety and hygiene. The library invested in special VR stands for cable management and in anti-bacterial, odourless wipes for cleaning the headset between uses. However, the behind-the-scenes administrative work required from our staff to coordinate, for example, with the other users of the lobby, could preferably be somewhat lower. Ideally, the VR point would have had its own dedicated place, but that did not prove to be possible at this time.

The Oulu City library is looking forward to the future versions of this prototype application. In the short term, there 


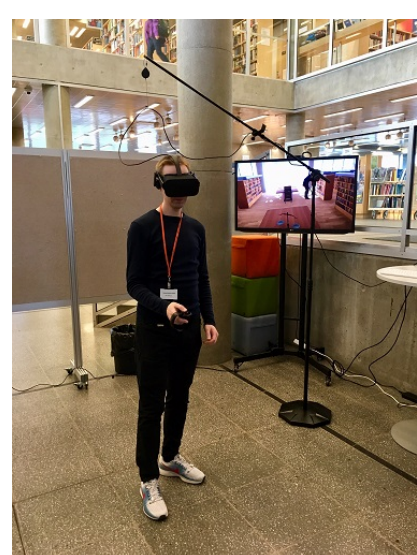

Figure 4: The public VR point at the Oulu City Library are some minor issues in the application that need to be addressed, such as incorrect scale regarding parts of the library interior, unbalanced audio levels, and the need for an alternative, more accessible control scheme for those who have motor difficulties with the default controls. In the long term, the main direction for improvement could be the implementation of more library-specific functionalities such as the e-book collection, book talks and live-streamed events.

From the Oulu City Library's perspective, VR technology is here to stay. With the tendency of new technologies to both improve their capabilities and lower their price over time, public libraries need to be ready for the day when VR is as prevalent part of society as books, music and movies are now. Public libraries are on a never-ending quest for improving the discoverability of their collections, and here VR technology has already shown promise.

\section{Video}

The video is available in YouTube:

https://www.youtube.com/watch?v=JJiMtdNv32

\section{Acknowledgements}

This work has been supported by the Open Innovation Platforms spearhead project (A70202) and the Open City Mode as Open Innovation Platform pilot project (A71143) funded by the ERDF and the City of Oulu under the Six City Strategy program, and the COMBAT project (293389) funded by the Strategic Research Council at the Academy of Finland. We wish to express our gratitude to all study participants and the Oulu City Library.

\section{REFERENCES}

1. Svanhild Aabø, Ragnar Audunson, and Andreas Vårheim. 2010. How do public libraries function as meeting places? Library \& Information Science Research 32, 1 (2010), 16-26.

2. Nonny De la Peña, Peggy Weil, Joan Llobera, Elias Giannopoulos, Ausiàs Pomés, Bernhard Spanlang, Doron Friedman, Maria V Sanchez-Vives, and Mel Slater. 2010. Immersive journalism: immersive virtual reality for the first-person experience of news.

Presence: Teleoperators and virtual environments 19 4 (2010), 291-301.

3. Gerard Llorach, Alun Evans, and Josep Blat. 2014. Simulator sickness and presence using HMDs: comparing use of a game controller and a position estimation system. In Proceedings of the 20th ACM Symposium on Virtual Reality Software and Technology. ACM, 137-140.

4. Matti Pouke, Johanna Ylipulli, Ilya Minyaev, Minna Pakanen, Paula Alavesa, Toni Alatalo, and Timo Ojala 2018. Virtual Library - Blending Mirror and Fantasy Layers into a VR Interface for a Public Library. In Accepted to the 17th International Conference on Mobile and Ubiquitous Multimedia.

5. Lisa Rebenitsch and Charles Owen. 2016. Review on cybersickness in applications and visual displays. Virtual Reality 20, 2 (01 Jun 2016), 101-125.

6. Jesper Simonsen and Toni Robertson. 2012 Routledge international handbook of participatory design. Routledge. 86-116 pages.

7. Pertti Vakkari, Svanhild Aabø, Ragnar Audunson, Frank Huysmans, and Marjolein Oomes. 2014. Perceived outcomes of public libraries in Finland, Norway and the Netherlands. Journal of Documentation 70, 5 (2014), 927-944. 
8. YLE News. 2018. Finnish libraries experience renaissance with renewed investment. (September 2018). https://yle.fi/uutiset/osasto/news/ finnish_libraries_experience_renaissance_with_ renewed_investment/10395160 Accessed 9 September 2018.
9. J. Ylipulli, A. Luusua, and T. Ojala. 2017. On Creative Metaphors in Technology Design: Case "Magic". In Proceedings of the 8th International Conference on Communities and Technologies (C\&T'17). ACM, New York, NY, USA, 280-289. DOI :

http://dx.doi.org/10.1145/3083671.3083691 